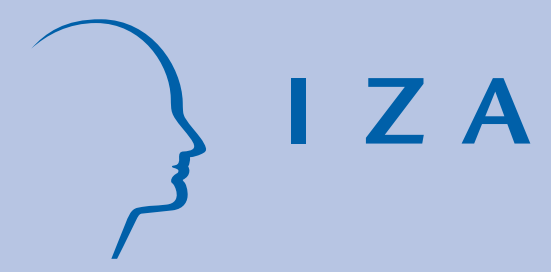

IZA Policy Paper No. 97

A Feasible Unemployment-Based Shock Absorber for the Euro Area

Andrea Brandolini

Francesca Carta

Francesco D'Amuri

February 2015 


\title{
A Feasible Unemployment-Based Shock Absorber for the Euro Area
}

\author{
Andrea Brandolini \\ Bank of Italy \\ and IZA
Francesca Carta
Bank of Italy
Francesco D'Amuri
Bank of Italy
and IZA
Policy Paper No. 97
February 2015

\author{
IZA \\ P.O. Box 7240 \\ 53072 Bonn \\ Germany \\ Phone: +49-228-3894-0 \\ Fax: +49-228-3894-180 \\ E-mail: iza@iza.org
}

The IZA Policy Paper Series publishes work by IZA staff and network members with immediate relevance for policymakers. Any opinions and views on policy expressed are those of the author(s) and not necessarily those of IZA.

The papers often represent preliminary work and are circulated to encourage discussion. Citation of such a paper should account for its provisional character. A revised version may be available directly from the corresponding author. 
IZA Policy Paper No. 97

February 2015

\section{ABSTRACT}

\section{A Feasible Unemployment-Based Shock Absorber for the Euro Area}

This paper contributes to the debate on the design of a centralised fiscal tool absorbing country-specific negative shocks in the euro area. Based on theoretical insights, it identifies the broad characteristics that a shock absorber based on unemployment should have in order to be incentive-compatible and politically feasible. It then derives empirically the combination of activation thresholds, experience rating, eligibility criteria, and benefit generosity which define the systems offering the highest stabilisation for given levels of redistribution, accounting for the large variation in benefit take-up rates across European countries. The analysis suggests that the shock absorber should: i) give rise to macro crossnational transfers, mimicking those that would be generated by a notional euro-wide unemployment benefit scheme of minimal coverage and generosity; ii) be activated by a trigger; and iii) feature partial experience rating. The simulation results, confirmed by robustness checks, show that even systems that do not redistribute resources between countries can have a non-negligible stabilisation impact in the medium run. Low benefit takeup rates in Southern Europe substantially reduce the stabilisation properties and the size of the scheme.

JEL Classification: E6, J65, H53

Keywords: unemployment benefits, absorption of macroeconomic shocks, fiscal union

Corresponding author:

Francesco D'Amuri

Bank of Italy

Via Nazionale 91

00184, Rome

Italy

E-mail: francesco.damuri@bancaditalia.it

\footnotetext{
*We are grateful for valuable comments to Alfonso Arpaia, Tony Atkinson, Fabrizio Balassone, Matteo Bugamelli, Georg Fischer, Paolo Sestito, Luigi Federico Signorini and seminar participants at the Bank of Italy and at the European Commission (DG Employment, Social Affairs and Inclusion). This paper is a revised version of the Bank of Italy Occasional Paper No. 254. The views expressed here are ours alone; in particular, they do not necessarily reflect those of the Bank of Italy.
} 


\section{Introduction}

The sovereign debt crisis of 2011-13 has exposed the limits of a monetary union with fully decentralised fiscal policies. In the impossibility of managing country specific negative income shocks through monetary policy and exchange rate fluctuations, national governments can only resort to counter-cyclical fiscal policy to stabilise the economy (e.g. Galì and Monacelli, 2008; Ferrero, 2009). In practice, they may have little room for manoeuvre due to the interplay of the union fiscal rules and the limited access to capital markets whenever the fiscal position is deteriorated. A centralised fiscal tool could help absorbing idiosyncratic negative shocks (Bordo et al., 2013; Farhi and Werning, 2014).

This idea has long been present in the debate on the European unification, at least since the reports prepared by the expert commissions chaired by Marjolin (1975) and MacDougall (1977), and later by Delors (1989). It has gained new momentum in the midst of the sovereign debt crisis with the suggestion of the report of the Four Presidents to create "An EMU fiscal capacity with a limited asymmetric shock absorption function” (Van Rompuy, 2012, p. 11). Critics fear that such a capacity could foster moral hazard and weaken the incentives to promote painful growth-enhancing reforms, but the thorniest issue is probably the cross-countries income redistribution that it could imply. As put by Bargain et al. (2013, p. 380), "in order to achieve significant income stabilization effects through the introduction of an EU tax and transfer system, that system would have to be large. However, this would lead to significant redistributive effects, which will make the reform difficult to sell politically”.

In this paper we investigate whether a centralised shock absorber can offer non-negligible stabilisation of the business cycle, while being incentive compatible and limited in the extent of cross-country redistribution. Consistently with the early proposals and with those recently advanced by commissioner Andor (2014) and the European Parliamentary Research Service (del Monte and Zandstra, 2014), we focus on a common unemployment-based scheme. We envisage a Notional Euro-wide Unemployment Insurance (NEUI) that works through periodic aggregate transfers to and from a supranational fund parameterised to the expenditure that would be incurred by each country in presence of a common unemployment benefit (UB) scheme. The NEUI is "notional” because it mimics an individual-level insurance scheme but operates with transfers at the macro level. With respect to a rainy-day fund, this shock absorber is less subject to political discretion and is targeted to a specific shock clearly linked to the business cycle (entry into unemployment). To overcome problems of asymmetric information, transfers could be activated only in case of sufficiently large negative shocks and be parameterised to benefits of limited duration and replacement rate. In accordance with the subsidiarity principle, national schemes would remain in place, based on rules 
set by national governments; but the NEUI subsidy would be explicitly acknowledged in order to make citizens cognisant of European solidarity. Payments to the NEUI would be determined by a contribution rate that balances disbursements and receipts in the medium run, either for each country (full experience rating) or only for the EA as a whole (partial or no experience rating). Varying the generosity of the system and the degree of experience rating would imply different levels of macroeconomic stabilisation and cross-country redistribution.

Within these boundaries, it is possible to design many different schemes that differ for the budgetary equilibrium condition, the eligibility criteria, the maximum duration of the benefit, and the trigger activating the program. We simulate the functioning of 72 schemes, either assuming that all job losers apply and receive the benefit (full recipiency) or exploiting the available information on those receiving benefits (actual recipiency). The latter simulations account for country differences in eligibility, duration and take-up of the benefits, which lead to lower financial flows, particularly in Southern Europe. To estimate the impact on GDP, we assume that net transfers imply a rise in consumption taxes for contributors and in public investments for beneficiaries, and we then apply the European Commission fiscal multipliers. In our baseline simulations, we consider the period 2002-12 for ten of the twelve countries that continuously adopted the euro during that period (EA10). Empirical results, robust to the choice of the multipliers and to changes in the estimation period, show that in the majority of cases the scheme implying the lowest cross-country redistribution for a given level of stabilisation features a benefit equal to 50 per cent of the average wage for all employees experiencing a job termination, eight months maximum duration, and a trigger based on employment dynamics. From the methodological standpoint, our main contribution is to show how the selection of preferable schemes can be framed in terms of the comparison between macroeconomic stabilisation and cross-country redistribution.

The rest of the paper is organised as follows. Section 2 discusses theoretical insights on how to draw a feasible and incentive-compatible shock absorber. Section 3 stresses the importance of distinguishing between the unemployed and the UB recipients, describes simulated schemes, and shows how to evaluate them. Section 4 presents the simulation results and tests their robustness. Section 5 reviews the existing literature. Section 6 concludes.

\section{Design of a feasible and incentive-compatible scheme}

Even before the launch of the euro, many researchers underlined the need for a centralised fiscal policy to guarantee inter-regional redistribution vis-à-vis asymmetric shocks; in absence of it, the stability of the monetary union could have been undermined (Fatàs et al, 1998). The Euro Area (EA) satisfies the conditions which make a centralised fiscal policy desirable, even more than other 
federations (the United States, Canada, Belgium): reduced internal labour mobility, sticky prices and wages, incompleteness of financial markets limiting the scope for national counter-cyclical fiscal policy. Taking as given the need for an integrated fiscal intervention, some theoretical issues need to be addressed, in this second best framework, in the design of the NEUI.

First, the imperfect verifiability of national behaviours by a central supranational authority creates familiar moral hazard problems, which stem from both the adoption of poor and inadequate policies at national level, and the possibility of administrative manipulation of the scheme (Vandenbroucke, 2013). Having a buffer system in case of adverse shocks, national governments could refrain from carrying out structural reforms to reduce the national risk or to help the economy to stabilise (Persson and Tabellini, 1996a). When the distribution of adverse shocks is asymmetric across countries and national governments cannot credibly commit to pursue reforms or repay the debt, low risk countries might not accept full risk sharing, since it involves redistribution towards high risk countries (Persson and Tabellini, 1996b), and may even opt for leaving the federation (Aronsson et al., 2012). On the other hand, the decentralised implementation of a supranational scheme faces asymmetric information problems on the identification of beneficiaries by national authorities, which might overestimate them to get more funds. Second, there is the moral hazard problem at the individual level, as distinct from the one at the national level, which is typically associated with unemployment insurance: more generous benefits might induce individuals to reduce their job-search effort, though income support provides liquidity to allow them to find a better match for their skills (Chetty, 2008). Third, the subsidiarity principle imposes constraints. A scheme increasing the generosity of unemployment insurance beyond the existing settings could be seen as overruling a country's specific preferences. The intervention could be however motivated by reference to best practices as well as by the need to harmonise existing schemes.

These considerations lead us to identify the following feasibility criteria:

1. Entitlements, replacement rate and duration of the benefit are bounded by the corresponding features of the national schemes currently in place. This option does not affect the individual moral hazard problem, since it does not alter the amount and duration of the existing benefits; it respects the subsidiarity principle, as it does not modify national schemes with a top-down approach; it limits the amount of resources involved.

2. Coverage is restricted to individuals losing their job and for a limited period after job termination. Excluding long-term unemployed, whose incidence tends to be associated with a country's structural problems, diminishes the risk of permanent redistribution across countries and contains the country moral hazard problem, as it does not reduce the incentive to pursue reforms which improve the functioning of the labour market. Such a system is also easier to administer, since it does not target all the unemployed but only those who are already eligible for 
the UB scheme; as a consequence, it could be run by existing agencies.

3. There is experience rating. Assuming that countries receiving more should also contribute proportionately more reduces the country moral hazard problem and implies no cross-national redistribution in the medium run.

4. Activation depends on a trigger. The existence of a trigger activating the system only in case of sizeable negative shocks strengthens the insurance aspect of the scheme (Gros, 2014) and could further limit the amount of transferred resources; however, it would not impair the stabilisation capacity in critical situations, without the need of a discretionary political decision.

The NEUI is micro based, as it targets a specific transfer (a basic unemployment subsidy) in a way that tries to be incentive-compatible both for countries and individuals, not intrusive of national systems, and easy to be run by existing agencies. Its further advantage is that it makes the existence of the risk sharing mechanism within the monetary union clearly visible to citizens, enhancing the sense of solidarity and trust in European institutions. However, the NEUI works at the macro level, through variations in the funds available to each country; such variations could be obtained by altering yearly contributions to the European Union (EU) budget. From this perspective, it mainly alleviates countries' fiscal constraints, acting as an automatic rainy-day fund.

While these considerations help us thinking about the design of the NEUI, they still allow for a great number of alternatives. How can we evaluate them? There are two decisive aspects: the degree of macroeconomic stabilisation, on one side, and the extent of cross-country redistribution, on the other. Our aim is to locate each alternative scheme in this bi-dimensional space and to draw an efficiency frontier that makes transparent to policy makers which scheme has to be preferred to the others in terms of both stabilisation and redistribution. We hence need further assumptions concerning the financing of the scheme and the utilisation of the national resources freed by its introduction. As only net transfers matter for estimating the stabilisation effects, we assume that they imply a rise in the consumption tax in contributing countries, while they release resources used to finance public investments in benefiting countries. The impact on GDP is then gauged by applying the multipliers adopted in its forecasting exercises by the European Commission (2010): a 0.4 multiplier for consumption tax increases and a 0.9 multiplier for increases in public investments.

\section{Simulation set-up}

In this paper we exploit the richness of the micro-data of the EU Labour Force Survey (EULFS) collected by Eurostat (missing data are imputed by country-specific regressions). The analysis focuses on the period 2002-12 for ten of the twelve countries that continuously adopted the euro over that period (Ireland and the Netherlands are not included because of data problems). Using 
these data, we simulate 72 different settings for the NEUI, broadly compatible with the theoretical insights sketched above. The schemes vary along five dimensions: three define the notional UB (coverage, replacement rate, duration); two define the rules governing the functioning of the absorber (activation trigger, experience rating). Next, we discuss the distinction between ILO unemployed and UB recipients, the simulated schemes, and their evaluation method.

\subsection{ILO unemployed and UB recipients}

The relative incidence in working age population of the unemployed, as defined by the ILO, and the UB recipients, i.e. individuals receiving unemployment-related transfers, substantially differ across the EA10 countries, although they show similar tendencies within each country.

In Austria, Germany, Finland, France and Luxembourg, the incidence of UB recipients always tracks very closely that of the unemployed; their relative incidence is close to one and steady over time. This evidence hints that most unemployed workers have access to the benefits and actually claim them (high take-up rates); moreover, individuals who stop actively looking for a job lose the benefits. In Belgium, the UB recipient incidence on working age population is much higher than that of the unemployed, as the UB system is virtually open-ended. In Spain, Greece, Italy and Portugal, the incidence of UB beneficiaries is substantially lower than that of the unemployed. This may reflect strict eligibility criteria and short duration of the benefits as well as low take-up rates. These results are confirmed when the analysis is restricted to individuals who are generally entitled to benefits such as those who declare to have been employed with a permanent contract in the year prior to the survey and are later dismissed.

This evidence emphasises that reliable estimates of the NEUI need to take into account that not all unemployed receive the benefits and not all beneficiaries are unemployed according to the ILO definition. Thus, we analyse the hypotheses of full recipiency (all job terminations are covered) and actual recipiency (eligibility criteria and take-up behaviour reproduce current patterns). As short-time compensation schemes used to temporarily reduce labour input without massive layoffs are close substitutes of UB schemes (e.g. Arpaia et al., 2010), their mutual interactions should also be considered (Fuchs, 2013). This analysis is prevented by the lack of relevant data.

\subsection{Main features of the notional unemployment benefit}

Coverage, replacement rate and duration of the benefit are the central features of any unemployment insurance, although it must be borne in mind that many more aspects distinguish these systems (Atkinson and Micklewright, 1990). Differences among the EA10 countries along these dimensions are still significant (Esser et al., 2013).

The number of monthly contributions necessary to be entitled to the subsidy is the main 
determinant of eligibility and, hence, coverage. Unfortunately, the EU-LFS data do not report any information about the eligibility of workers to the unemployment insurance, neither any satisfactory proxy such as the number of months of paid work before job termination. Thus, to gauge the impact of eligibility criteria we assume that the simulated schemes cover either all employees experiencing a job termination (dismissals and contract expiration), or dismissed employees with a permanent contract only. The first coverage is too broad, whereas the second is too narrow. These assumptions are illustrative and not to be taken literally: temporary workers are generally entitled to receive the unemployment subsidy provided that they have a sufficient contributory record; on the other hand, as just seen, benefit take-up can be partial. Thus, assuming full coverage of dismissals and contract expirations provides an upper bound to the level of unemployment-related expenditure, while using actual recipiency results in estimates that should be as close as possible to actual levels.

The amount of the unemployment subsidy is usually linked to previous earnings, possibly with a cap. As we lack the relevant information, we take average earnings as a reference for the UB level. Consistently with the idea that the NEUI is encompassed by the existing national schemes, we set the replacement rate at either 35 or 50 per cent and the maximum duration to either three or eight months. These figures are mostly lower than the corresponding national values.

\subsection{Activation and funding}

According to Gros (2014, p. 203), the EA does not need “... a system that offsets all shocks by some small fraction, but a system that protects against shocks that are rare, but potentially catastrophic”. To allow for this possibility, we simulate systems which vary by the condition which activates the scheme in response to a country-specific shock. Linking the activation of the scheme to the shock severity has the twofold advantage of reducing the size of cross-country financial flows, while offering a stabilising tool when it is most needed, and of limiting the room for individual countries’ opportunistic behaviour by reducing potential long-term redistribution.

The main issue is the choice of the trigger variable. The output gap is a variable extensively used in the European fiscal surveillance framework, but its estimates in real time often suffer from big revisions and can even change in sign (Kempkes, 2012; Dullien, 2014b). Employment or unemployment are less liable to this criticism, but follow the economic cycle with a lag (amplified by the delay in the release of relevant statistics), holding up the activation of the scheme during the early phases of a downturn. Recent proposals take as trigger variable the unemployment rate (Beblavý and Maselli, 2014; Dolls et al., 2014), the short-term unemployment rate (Beblavý et al., 2015), or the 4-12 month unemployment rate (Epaulard, 2014). Eichhorst and Wozny (2014) argue that the trigger variable should be the interest rate for a certain bond, as credit market constraints are the main rationale for introducing the euro-wide unemployment insurance. 
We consider three hypotheses: the NEUI is always active; the NEUI is active only for countries experiencing a drop in the output gap greater than or equal to half standard deviation of the output gap calculated across all considered countries; the NEUI is active only for countries experiencing a fall in employment greater than or equal to 20 per cent of the standard deviation of the changes in employment levels calculated across all countries. Either threshold is admittedly arbitrary but it is such that the scheme is activated in a historically significant number of cases.

As regards funding, a natural starting point is to assume that the NEUI is in equilibrium over a period of $T$ years. The balanced budget condition can be written as:

$$
\sum_{i=1, \ldots, I} \sum_{t=1, \ldots, T} \tau_{i t} c_{i t}=\sum_{i=1, \ldots, I} \sum_{t=1, \ldots, T} \min \left[R w_{i t} M_{i t}, B_{i t}\right] U_{i t} .
$$

The left-hand side is the total revenue, which is the sum of all payments made to the scheme by each country $i, i=1, \ldots, I$, in each year $t, t=1, \ldots, T$. The annual payments are computed by applying the national rate $\tau_{i t}$ to the chosen tax base $c_{i t}$. The right-hand side is the total expenditure and is similarly computed by summing annual expenditures across all countries. These are calculated by multiplying the mean benefit by the number of beneficiaries $U_{i t}$. In (1) the benefit is capped to a level $B_{i t}$, which can be set equal to a fraction of the median national income: the actual benefit is then the minimum between $B_{i t}$ and the product of the fixed replacement rate $R$, the average monthly wage $w_{i t}$, and the number of monthly benefits paid by the scheme $M_{i t}$. In what follows we assume that there is no benefit cap. As the expenditure side is defined by the characteristics of the NEUI, equation (1) defines the national contribution rates. We take these rates to be fixed over time and drop the subscript $t$.

With full experience rating each country is assumed to be in equilibrium over the whole time period $T$. Thus, (1), with no benefit cap, turns into

$$
\sum_{t=1, \ldots, T} \tau_{i} c_{i t}=\sum_{t=1, \ldots, T} R w_{i t} M_{i t} U_{i t}, \quad \text { for any } i=1, \ldots, I,
$$

which yields the country-specific equilibrium contribution rate:

$$
\tau_{i}=\frac{\sum_{t=1, \ldots, T} R w_{i t} M_{i t} U_{i t}}{\sum_{t=1, \ldots, T} c_{i t}} .
$$

In this case, country $i$ could be benefitting from or contributing to the system in a given year $t$, but its position would be balanced over $T$ years. There is no redistribution across countries over the time period, but the NEUI may alleviate liquidity constraints of countries in recessions, as it can run surpluses and deficits. On the other hand, countries with higher unemployment-related expenditures are bound to set higher $\tau_{i}$.

At the other extreme, assuming that there is no experience rating, the contribution rate is the 
same for all countries, and the balanced budget condition becomes

$$
\sum_{i=1, \ldots, I} \sum_{t=1, \ldots, T} \tau c_{i t}=\sum_{i=1, \ldots, I} \sum_{t=1, \ldots, T} R w_{i t} M_{i t} U_{i t},
$$

which defines the common contribution rate

$$
\tau=\frac{\sum_{i=1, \ldots, I} \sum_{t=1, \ldots, T} R w_{i t} M_{i t} U_{i t}}{\sum_{i=1, \ldots, n} \sum_{t=1, \ldots, T} c_{i t}} .
$$

In this case, income is redistributed from low to high unemployment-spending countries. Country i's cumulated net position is equal to $\left(\tau-\tau_{i}\right) \sum_{t=1, \ldots, T} C_{i t}$ : it is a net contributor (beneficiary) if $\tau>\tau_{i}$ ( $\tau<\tau_{i}$ ), though total transfers and payments net out over the whole period $T$.

We also explore the NEUI with partial experience rating that is halfway between the two previous options. In this case, individual countries' equilibrium rates are calculated as in (3a) up to a yearly threshold of 0.2 per cent of GDP. To make up for the loss in contributions and keep the fund balanced over the whole interval, countries below the cap contribute to the fund an additional fixed proportion of their GDP relative to what they would pay under (3a).

As regards the tax base $c$, differently from other works, we assume that the NEUI is financed by a consumption tax rather than a tax levied on wages and salaries. This option does not impact on the level of the tax wedge on labour, which is considered to be already high in many countries. Moreover, the additional resources freed by the NEUI are used for countercyclical fiscal policies sustaining investments, not for raising the generosity of passive labour market policies. As positive effects are felt by the whole economy, a scheme funded by payroll taxes is less justifiable as it would imply an income transfer from employees and employers to the rest of the economy.

The NEUI aggregate transfers could take place through appropriate variations of the national contributions to the EU budget, with no actual payments occurring across countries, or through a centralised fund as suggested by Lellouch and Sode (2014). In all cases, we suppose that there are no interest payments to be paid (received) when a country is in deficit (surplus).

\subsection{Evaluation of alternative schemes}

The aim of our simulations is to characterise the relationship between macroeconomic stabilisation and cross-country redistribution. Stabilisation is measured by the reduction in GDP volatility, defined as the percentage reduction in the coefficient of variation of the GDP series over the time period considered. The GDP series that would have obtained in the presence of the NEUI is simulated by multiplying each net transfer paid to the scheme by 0.4 (the consumption multiplier) and each net transfer received from the scheme by 0.9 (the investment multiplier). These are conservative values, as they assume that there are no liquidity constraints and that interest rates are 
above the lower bound; for instance, relaxing these assumptions would entail a value of the investment multiplier of 1.1 (European Commission, 2010).

The index of redistribution is given by the sum of the squared deviations of the unique contribution rate that balances the system for the EA as a whole from the national contribution rate

that balances the system for each country: $\sum_{i=1, \ldots, I}\left(\tau-\tau_{i}\right)^{2}$. This formulation is preferred to half the sum of the absolute deviations to give more weight to larger deviations.

Simulations are made ex post on historical data. Thus, they implicitly assume that each country knows in advance the future unemployment-related expenditures in order to balance the NEUI over the prefixed time interval. In a real world scenario, countries could create a common fund in the first years of operation of the scheme in order to face unexpected shocks, while contribution rates could be gradually adjusted ex post in order to satisfy the constraints imposed on the extent of cross-country redistribution. This complication is not considered.

\section{Simulation results}

For each of the 72 schemes obtained by combining the alternative hypotheses described above, we estimate the reduction in GDP volatility and the extent of cross-country redistribution over the period 2002-12. We estimate the number of beneficiaries $U_{i t}$ in country $i$ and year $t$ from the micro-data of the EU-LFS, while we calculate the average monthly wage $w_{i t}$ as the mean employees’ compensation per employee from the national accounts.

We first identify the schemes with full experience rating that offer the maximum level of stabilisation over the cycle. They do not entail any cross-country redistribution over the time period, but can still offer some stabilisation through income smoothing, that is by enabling a country to reduce its contribution to the EU budget in downturns and to pay higher contributions in upswings. For the same level of stabilisation, these schemes are preferred to those with no or partial experience rating because the absence of cross-country redistribution is appealing from the political standpoint. Schemes with no or partial experience rating offering higher levels of stabilisation are selected by taking, for each quintile of the stabilisation distribution, the one implying the lowest redistribution. As a consequence, the efficiency frontier includes a scheme with full experience rating and the five best schemes with no or partial experience rating (provided that at least five out of the 48 schemes offer higher stabilisation than the best scheme with full experience rating).

The results of the simulations are summarised by locating each scheme in a graph showing the extent of macroeconomic stabilisation on the vertical axis and of cross-country redistribution on the horizontal axis (Figure 1). The efficiency frontier shows the preferable schemes, i.e. those that 
would produce the highest stabilisation for any given level of redistribution. The schemes on the efficiency frontier always cover both job dismissals and terminations, and tend to offer a maximum duration of eight months; results are less clear-cut on the level of the replacement rate. Schemes activated only in the face of large shocks are preferred to those who are always active. Full experience rating can still produce non negligible levels of stabilisation; without full experience rating, the preferable option may be to foresee a contribution rate cap (partial experience rating).

In general, irrespective of the presence of experience rating and both taking into account full or actual recipiency, the scheme offering the highest stabilisation is one envisaging a 50 per cent replacement rate for all the employees experiencing a job termination, eight months duration, and a trigger based on employment dynamics. Table 1 shows the financial flows and the impact on GDP of this scheme. Assuming full recipiency, the maximum stabilisation of models with full experience rating is a reduction of the coefficient of variation of GDP by 0.03 per cent, while the EA10 GDP increases by 0.04 . Models with partial experience rating outperform those without any link between benefits and contributions, which are never on the efficiency frontier; they offer more than three times the stabilisation achievable with full experience rating and a substantially higher boost to GDP (0.1 per cent in the EA10). All the schemes on the efficiency frontier feature a trigger and cover both dismissed individuals and those with an expired contract; no clear pattern emerges concerning replacement rates while, with one exception, schemes with a eight months maximum duration are preferred to schemes with shorter durations. These regularities are confirmed assuming actual recipiency, but the stabilisation performance is reduced: without experience rating, the most stabilising scheme achieves a 0.05 per cent reduction in GDP volatility.

\subsection{Robustness checks}

We test the robustness of these results to the values chosen for the multipliers and to the time interval considered. First, we consider two alternative hypotheses on multipliers: in one case we raise the values for both inflows and outflows to 1 , thus reducing the bias implicit in the fact that the consumption multiplier is smaller than the investment one; in the other case, we raise the multiplier for transfers received from 0.9 to 1.5 (the multiplier for investment subsidies estimated by the European Commission, 2010), while retaining the value of 0.4 for transfers paid. Second, we examine three other time intervals: 2002-10, 2003-11 and 2004-12. We run the whole evaluation exercise for all twelve possible combinations of the three pairs of multipliers and the four time periods, separately for full and actual recipiency. Results are surprisingly robust: out of 1,728 $(=3 \times 4 \times 2 \times 72)$ simulations, the scheme with a 50 per cent replacement rate and eight months duration, covering both dismissals and contract expirations and activated by an employment-based trigger is the one preferred in the large majority of cases. This conclusion holds true with or without 
experience rating.

\subsection{Cross-national financial flows and macroeconomic stabilisation}

Table 1 reports also the cumulated national financial flows generated by the preferred scheme. The position of the NEUI fund can be negative or positive in each year, but is balanced over the time interval. With full recipiency and full experience rating, the NEUI generates no cumulated cross-country cash flows during the period 2002-12. Nevertheless, all countries are net beneficiaries in at least one year. Assuming the standard values for the multipliers, the impact on GDP is positive everywhere, and especially large in countries hardest hit by the crisis (Spain, Portugal, Greece). With partial experience rating, cumulated cash flows can deviate significantly from zero for each country, but the fund balances over the time interval. Spain is again the biggest beneficiary (a net transfer equal to 0.3 per cent of its GDP, generating a 0.5 per cent additional GDP growth), together with Portugal and Greece, while the biggest contributors, in GDP terms, are Luxembourg, Austria and Belgium. With actual recipiency, the size of financial flows is reduced and the impact on output is considerably smaller than with full recipiency, in particular for countries with low take-up rates. With full experience rating, for instance, the impact on GDP does not change in Germany (0.02 per cent), while it decreases from 0.03 to 0.01 per cent in Italy.

The period 2002-12 includes the most acute post-war recession and represents a test of the NEUI in an unusually stressed environment. To simulate its functioning in more normal times, we estimate the financial flows for the shorter pre-crisis period 2002-08. With full recipiency, the biggest beneficiary without full experience rating is Finland (receiving 0.07 per cent of its GDP), followed by Spain and Germany (0.06 and 0.02 per cent, respectively), while the biggest contributors are Belgium, France, Greece, Italy and Luxembourg (0.03 per cent). Beneficiaries and contributors do not change with actual recipiency, but the dimensions of the flows are smaller. The sensitivity of the net position of countries to different time intervals suggests that it is misleading to judge the political feasibility of the NEUI by focusing on recent years only.

A reference for the stabilisation offered by the NEUI is provided by the budgetary margins allowed by the current European fiscal rules. The EU fiscal surveillance defines the cyclically adjusted budget balance $(C A B B)$ as the public budget balance net of the part attributable to the cyclical conditions and hence unrelated to the government fiscal stance (Mourre et al., 2013):

$$
C A B B=\frac{R-G}{Y}-\varepsilon\left(\frac{Y-Y^{P}}{Y^{P}}\right)=\frac{B}{Y}-\varepsilon O G,
$$

where $B$ is the general government balance equal to revenues minus expenditures, $B=R-G, Y$ is GDP, $Y^{P}$ is potential GDP, and $\varepsilon$ is the country-specific semi-elasticity of the budget balance to the 
output gap $O G=\left(Y-Y^{P}\right) / Y^{P}$. The term $\varepsilon O G$ is a straightforward quantification of the budgetary leeway left to countries to stabilise business cycle without altering their fiscal stance. If countries with $Y<Y^{P}$ expand public investments by $\varepsilon O G$, while countries with $Y>Y^{P}$ raise consumption taxes by $-\varepsilon O G$, the current fiscal rules allow for a 0.43 per cent reduction in the GDP coefficient of variation for the EA10 (using the standard multipliers and the output gap estimates drawn from European Commission, 2014). The stabilisation offered by the NEUI with full experience rating is 30 times smaller with actual recipiency and 7 times smaller with full recipiency; without full experience rating, stabilisation is larger, up to a fourth of that allowed by the Fiscal Compact, with full recipiency. The magnitude of the stabilisation offered by the NEUI is only some fraction of that implicit in the current fiscal rules, but is not negligible, in particular if compared to the very limited cross-country financial flows involved (from zero with full experience rate to a maximum of 0.09 per cent of GDP for Luxembourg with partial experience rating).

\section{Related literature}

The recent policy interest has stimulated the research on European UB schemes and the simulation of their macroeconomic and distributive effects. The main studies include six macroeconomic simulations and two exercises drawing on the EUROMOD tax-benefit microsimulation model (based on the EU-SILC); only this paper uses the EU-LFS micro-data (Table 2).

The work by Jara and Sutherland (2014) is not directly comparable to the others, as it only estimates potential distributive effects. Using EUROMOD, it calculates the extent to which two European schemes would extend the coverage of the unemployment insurance in case of job loss, increase the benefits, and stabilise household net incomes for the whole of employed persons. By construction, the NEUI simulated in our paper has no direct impact on income distribution, as it is encompassed by existing national UB schemes. The indirect effects generated by macroeconomic stabilisation cannot be estimated in our framework.

The other papers focus on macroeconomic aspects. They all estimate the total revenues and disbursements of the European UB fund, but their results cannot be easily compared given the differences in time periods and country coverage as well as in the assumed features on the European UB schemes (replacement rate, duration and coverage of the benefit, activation trigger, experience rating). Among the papers assessing the extent of macroeconomic stabilisation, only Fichtner and Haan (2014) and Dullien et al. (2014) employ a fully-fledged macro-simulation model (NiGEM); all others rely on a simple application of fiscal multipliers. Unlike our paper, they consider only one value of the multiplier, common to both inflow and outflows. 
The most important single difference between our paper and the other macro-oriented papers is likely to be the definition of the labour force coverage. All studies focus on total or short-term unemployment. This implies that the self-employed and, with the exception of Dolls et al. (2014), first-job seekers are covered by the European unemployment insurance. This would be an important innovation over current practices, as the coverage would be extended to workers who are usually not insured by the exiting national UB schemes. Sometimes, this extension is lessened by restricting recipiency to a fraction of the chosen unemployment aggregate, based on some arbitrary value or the average share of unemployed who actually receive benefits. This adjustment leads to estimating smaller, and probably more realistic, total disbursements, but cannot capture the heterogeneity in entitlements and take-up behaviours across the labour force. This is the main reason why we use the micro-data from the EU-LFS, though the available information is only a rough approximation even in this case. Methodologically, the simulations by Dolls et al. (2014) where actual UB recipiency is estimated from the EU-SILC micro-data are the closest to ours assuming actual recipiency. Aside from the many simulation differences, accounting for actual rather than full recipiency reduces considerably benefit payments, in a proportion that differ from country to country.

\section{Conclusions}

The idea of a centralised fiscal tool, particularly a euro-wide UB scheme, is present in the debate on the European unification since the 1970s; the sovereign debt crisis has brought it back to centre stage. In this paper, we have discussed how the NEUI could be designed to temper moral hazard, enhance political feasibility, and be easily run by existing agencies. The NEUI works at the macro level, through variations in the funds available to each country, but mimics the aggregate transfers that would be generated by a fully-fledged social insurance. At the same time, defining transfers at the micro level improves targeting and makes the risk sharing mechanism within the monetary union more visible to European citizens.

We have simulated 72 schemes - differing by benefit coverage, replacement rate, duration, trigger variable, and experience rating - and evaluated the extent of macroeconomic stabilisation and cross-country redistribution that they would imply. These results, which are robust to the choice of the multipliers and of the estimation period, point at a scheme which foresees a 50 per cent replacement rate for all employees experiencing a job termination, eight months maximum duration, and a trigger based on employment dynamics, both with and without experience rating.

Assuming full recipiency, this scheme would reduce the coefficient of variation of GDP in the EA10 by 0.03 per cent with full experience rating and by 0.11 per cent with partial or no experience rating, though some cross-country redistribution would arise in the latter case. Assuming 
actual recipiency, particularly low in Southern European countries, the stabilisation performance is approximately halved. While with full experience rating each country's position would be balanced over time, with partial or no experience rating Spain and, to a lesser extent, Portugal would be the main beneficiaries in absolute terms; Italy, France and Germany would be the greatest contributors. Considering the pre-crisis period 2002-08, Spain and Germany would be the biggest beneficiaries, while France and Italy would keep being the biggest contributors. This evidence is a warning that the conclusions on cross-country redistribution are highly sensitive to the simulation period as well as to the assumption made on the recipiency of the benefit. In 2002-12, the stabilisation of the NEUI with full experience rating would be one thirtieth (actual recipiency) to one seventh (full recipiency) of that currently possible under the Fiscal Compact; this fraction would rise to a fourth with full recipiency and partial experience rating. Thus, the stabilisation due to the shock absorber is not negligible, especially if compared to the very limited cross-country financial flows involved.

The NEUI introduces incentives for national authorities to relax eligibility criteria and raise take-up rates in order to take full advantage of supranational transfers. The former incentive suggests that limits to its eligibility criteria may be appropriate, although this aspect is not modelled in the previous analysis due to lack of information. The latter incentive is a positive side effect of the scheme to the extent that it leads to improvements in the functioning of employment services in countries where take-up rates are low. In either case, the NEUI can be a factor encouraging crossnational standardisation of national UB rules in the EU (Paetzold and Van Vliet, 2014).

\section{References}

Andor, L. (2014). "Basic European Unemployment Insurance-The Best Way Forward in Strengthening the EMU's Resilience and Europe’s Recovery”, Intereconomics 49(4), 184189.

Aronsson, T., Micheletto, L., and Sjögren, T. (2012). "Public Goods in a Voluntary Federal Union: Implications of a Participation Constraint”, Uppsala Center for Fiscal Studies, Department of Economics, Working Paper 2012/12.

Arpaia, A., Curci, N., Meyermans, E., Peschner, J. and Pierini F. (2010). "Short time working arrangements as response to cyclical fluctuations”, European Economy 64.

Atkinson, A. B., and Micklewright, J. (1990). "Unemployment compensation and labor market transitions: a critical review”, Journal of Economic Literature 29(4), 1679-1727.

Bargain, O., Dolls, M., Fuest, C., Neumann, D., Peichl, A., Pestel, N., and Siegloch, S. (2013) "Fiscal Union in Europe? Redistributive and Stabilizing Effects of a European Tax-Benefit System and Fiscal Equalization Mechanism”, Economic Policy 28(75), 375-422. 
Beblavý, M., and I. Maselli (2014). “An Unemployment Insurance Scheme for the Euro Area: A simulation exercise of two options”, CEPS, Special Report 98.

Beblavý, M., D. Gros and Maselli, I. (2015). "Reinsurance of National Unemployment Benefit Schemes”, CEPS, Working Document 401.

Bordo, M.D., Jonung, L., and Markiewicz, A. (2013). “A Fiscal Union for the Euro: Some Lessons from History”, CESifo Economic Studies 59(3), 449-488.

Chetty, R. (2008). “Moral Hazard versus Liquidity and Optimal Unemployment Insurance”, Journal of Political Economy 116(2), 173-234.

del Monte, M., and Zandstra, T. (2014). “Common Unemployment Insurance Scheme for the Euro Area”, European Parliamentary Research Service-EPRS, PE 510.984.

Delors, J. (1989) “Regional Implications of Economic and Monetary Integration”, in Committee for the Study of Economic and Monetary Union (ed.), Report on Economic and Monetary Union in the European Community, Luxembourg, Office for Official Publications of the EC.

Dolls, M., Fuest, C., Neumann, D., and Peichl, A. (2014). “An Unemployment Insurance Scheme for the Euro Area? A Comparison of Different Alternatives using Micro Data”, ZEW, Discussion Paper 14-084.

Dullien, S. (2014a). “The Macroeconomic Stabilisation Impact of a European Basic Unemployment Insurance Scheme”, Intereconomics 49(4), 189-193.

Dullien, S. (2014b). A European Unemployment Benefit Scheme. How to Provide for More Stability in the Euro Zone. Gütersloh, Bertelsmann Stiftung.

Dullien, S., Fichtner, F., Haan, P., Jaeger, L., Jansen, M., Ochmann, R., and Tomasch, E. (2014). "Eine Arbeitslosenversicherung für den Euroraum als automatischer Stabilisator - Grenzen und Möglichkeiten”, DIW, Politikberatung Kompakt 86.

Eichhorst, W., and Wozny, F. (2014). “A Joint Unemployment Insurance for the European Economic and Monetary Union?”, IZA, Policy Paper 92.

Epaulard, A. (2014). “Contingent vs. Non-Contingent Unemployment Benefit Scheme for the EMU”, Paper presented at the Conference "Economic shock absorbers for the Eurozone”, Brussels, 20 June 2014.

Esser, I., Ferrarini, T., Nelson, K., Palme, J., and Sjöberg, O. (2013). "Unemployment Benefits in EU Member States”, Paper prepared for the European Commission, Directorate-General for Employment, Social Affairs and Inclusion.

European Commission (2010). “European Economic Forecast - Autumn”, European Economy, 7.

European Commission (2014), “Annual macro-economic database - 4 November 2014 release”, http://ec.europa.eu/economy_finance/db_indicators/ameco/index_en.htm.

Farhi, E., and Werning, I. (2014). “Fiscal unions”, Harvard University and MIT, Mimeo. 
Fatás, A., Andersen, T.M., and Martin, P. (1998). “Does EMU need a fiscal federation?”, Economic Policy 13(26), 165-203.

Ferrero, A. (2009). “Fiscal and monetary rules for a currency union”, Journal of International Economics 77(1), 1-10.

Fichtner, F., and Haan, P. (2014). “European Unemployment Insurance: Economic Stability without Major Redistribution of Household Incomes”, DIW Economic Bulletin 4(10), 39-50.

Fuchs, M. (2013). “Assessing the impact of an EMU UBS on diverse national benefits systems: (To what extent) Do we need common eligibility rules?”, Paper presented at the Conference “Let’s think out of the box”, Brussels, 11 October 2013.

Gali, J., and Monacelli, T. (2008). “Optimal monetary and fiscal policy in a currency union”, Journal of International Economics 76(1), 116-132.

Gros, D. (2014). “A Fiscal Shock Absorber for the Eurozone? Insurance with Deductible”, Intereconomics 49(4), 199-203.

Jara, H.X., and Sutherland, H. (2014). "The Effects of an EMU Insurance Scheme on Income in Unemployment”, Intereconomics 49(4), 194-199.

Kempkes, G. (2012). “Cyclical adjustment in fiscal rules: some evidence on real-time bias for Eu15 countries”, Deutsche Bundesbank, Discussion Paper 15.

Lellouch, T., and Sode, A. (2014). “An unemployment insurance scheme for the euro area”, TrésorEconomics 132.

MacDougall, D. (1977). "Report of the Study Group on the role of public finance in European integration”, Commission of the European Communities, Economic and Financial Series A13. Marjolin, R., (1975). "Report of the Study Group 'Economic and Monetary Union, 1980’”, Commission of the European Communities, EMU 63.

Mourre G., Isbasoiu, G., Paternoster, D. and Salto, M. (2014). “The cyclically-adjusted budget balance used in the EU fiscal framework: au update”, European Economy 478.

Paetzold, J., and Van Vliet, O. (2014), "EU Co-ordination and the Convergence of Domestic Unemployment Protection Scheme”, Journal of Common Market Studies 52(5), 1070-1089.

Persson, T., and Tabellini, G. (1996a). "Federal fiscal constitutions: Risk sharing and moral hazard”, Econometrica 64(3), 623-646.

Persson, T., and Tabellini, G. (1996b). "Federal fiscal constitutions: Risk sharing and redistribution”, Journal of Political Economy 104(5), 979-1009.

Van Rompuy, H. in close collaboration with Barroso, M.J., Juncker, J.-C., and Draghi, M. (2012). “Towards a genuine economic and monetary union”.

Vandenbroucke, F. (2013). “Automatic Stabilisers and a European Unemployment Benefit Scheme: How to Mitigate Moral Hazard?”, Paper presented at the Conference “Let’s think out of the 
box”, Brussels, 11 October 2013. 
Figure 1: The efficiency frontier

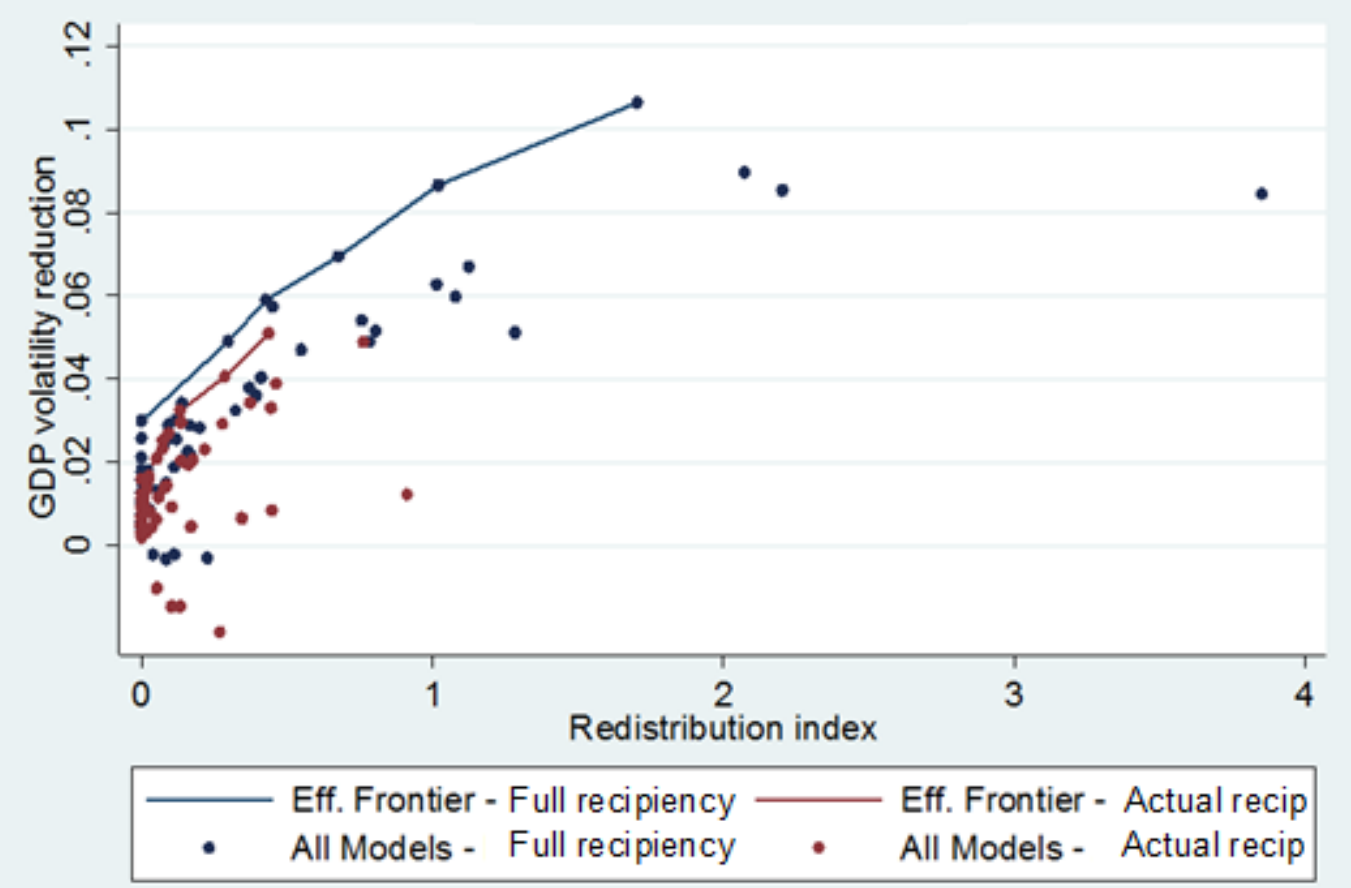

Source: authors' elaboration on EU-LFS data. Each point represents the Redistribution-Stabilisation pair of one of the 72 different notional UB schemes simulated in the paper. The GDP volatility reduction is equal to the reduction in the GDP coefficient of variation. The redistribution index is equal to the sum of the squared deviations of the unique contribution rate that balances the system for the area as a whole from the contribution rates that balances the system for each country, multiplied by a million. 
Table 1: Main results for the preferred scheme (1)

\begin{tabular}{|c|c|c|c|c|c|c|c|c|c|c|c|c|}
\hline \multirow[t]{3}{*}{ Country } & \multicolumn{6}{|c|}{ Full recipiency } & \multicolumn{6}{|c|}{ Actual recipiency } \\
\hline & \multicolumn{3}{|c|}{ Full experience rating } & \multicolumn{3}{|c|}{ Partial experience rating } & \multicolumn{3}{|c|}{ Full experience rating } & \multicolumn{3}{|c|}{ Partial experience rating } \\
\hline & $\begin{array}{l}\text { Overall } \\
\text { transfer } \\
\text { (million } €)\end{array}$ & $\begin{array}{l}\text { Overall } \\
\text { transfer (\% } \\
\text { of GDP) }\end{array}$ & $\begin{array}{l}\text { Impact on } \\
\text { GDP (\%) }\end{array}$ & $\begin{array}{l}\text { Overall } \\
\text { transfer } \\
(\text { million } €)\end{array}$ & $\begin{array}{l}\text { Overall } \\
\text { transfer (\% } \\
\text { of GDP) }\end{array}$ & $\begin{array}{l}\text { Impact on } \\
\text { GDP (\%) }\end{array}$ & $\begin{array}{l}\text { Overall } \\
\text { transfer } \\
(\text { million } €)\end{array}$ & $\begin{array}{l}\text { Overall } \\
\text { transfer (\% } \\
\text { of GDP) }\end{array}$ & $\begin{array}{l}\text { Impact on } \\
\text { GDP (\%) }\end{array}$ & $\begin{array}{l}\text { Overall } \\
\text { transfer } \\
(\text { million } €)\end{array}$ & $\begin{array}{l}\text { Overall } \\
\text { transfer (\% } \\
\text { of GDP) }\end{array}$ & $\begin{array}{l}\text { Impact on } \\
\text { GDP (\%) }\end{array}$ \\
\hline & \multicolumn{12}{|c|}{ Time interval: 2002-12 } \\
\hline Austria & 0 & 0 & 0.01 & $-2,312$ & -0.08 & 0.05 & 0 & 0 & 0.01 & $-1,105$ & -0.04 & 0.02 \\
\hline Belgium & 0 & 0 & 0.01 & $-2,679$ & -0.07 & 0.05 & 0 & 0 & 0.01 & $-1,151$ & -0.03 & 0.03 \\
\hline Germany & 0 & 0 & 0.02 & $-13,251$ & -0.05 & 0.08 & 0 & 0 & 0.02 & $-4,597$ & -0.02 & 0.04 \\
\hline Finland & 0 & 0 & 0.04 & -313 & -0.02 & 0.12 & 0 & 0 & 0.02 & -132 & -0.01 & 0.06 \\
\hline France & 0 & 0 & 0.02 & $-11,707$ & -0.06 & 0.07 & 0 & 0 & 0.01 & $-5,350$ & -0.03 & 0.03 \\
\hline Greece & 0 & 0 & 0.05 & 885 & 0.04 & 0.16 & 0 & 0 & 0.03 & -184 & -0.01 & 0.05 \\
\hline Italy & 0 & 0 & 0.03 & $-7,987$ & -0.05 & 0.08 & 0 & 0 & 0.01 & $-6,197$ & -0.04 & 0.02 \\
\hline Luxembourg & 0 & 0 & 0.01 & -341 & -0.09 & 0.04 & 0 & 0 & 0 & -143 & -0.04 & 0.02 \\
\hline Portugal & 0 & 0 & 0.07 & 1,805 & 0.10 & 0.22 & 0 & 0 & 0.04 & 550 & 0.03 & 0.10 \\
\hline Spain & 0 & 0 & 0.12 & 35,901 & 0.34 & 0.49 & 0 & 0 & 0.07 & 18,308 & 0.17 & 0.25 \\
\hline EA10 & 0 & 0 & 0.04 & 0 & 0 & 0.10 & 0 & 0 & 0.02 & 0 & 0 & 0.10 \\
\hline Redistribution (2) & & & 0 & & & 1.7 & & & 0 & & & 0.43 \\
\hline \multirow[t]{2}{*}{ Stabilisation (3) } & & & -0.03 & & & -0.11 & & & -0.02 & & & -0.05 \\
\hline & \multicolumn{12}{|c|}{ Time interval: 2002-08 } \\
\hline Austria & 0 & 0 & -0.02 & -309 & -0.02 & 0.03 & 0 & 0 & -0.01 & -214 & -0.04 & 0.01 \\
\hline Belgium & 0 & 0 & -0.03 & -602 & -0.03 & 0 & 0 & 0 & -0.01 & -263 & -0.03 & 0 \\
\hline Germany & 0 & 0 & 0.02 & 3,202 & 0.02 & 0.08 & 0 & 0 & 0.01 & 2,231 & -0.02 & 0.05 \\
\hline Finland & 0 & 0 & 0.07 & 778 & 0.07 & 0.14 & 0 & 0 & 0.03 & 312 & -0.01 & 0.07 \\
\hline France & 0 & 0 & -0.03 & $-3,411$ & -0.03 & 0 & 0 & 0 & -0.01 & $-1,487$ & -0.03 & 0 \\
\hline Greece & 0 & 0 & -0.03 & -385 & -0.03 & 0 & 0 & 0 & -0.01 & -168 & -0.01 & 0 \\
\hline Italy & 0 & 0 & -0.03 & $-2,842$ & -0.03 & 0 & 0 & 0 & -0.01 & $-1,239$ & -0.04 & 0 \\
\hline Luxembourg & 0 & 0 & -0.03 & -61 & -0.03 & 0.03 & 0 & 0 & -0.01 & -27 & -0.04 & 0.01 \\
\hline Portugal & 0 & 0 & 0 & -10 & 0 & 0.05 & 0 & 0 & -0.01 & -134 & 0.03 & 0.01 \\
\hline Spain & 0 & 0 & 0.06 & 3,641 & 0.06 & 0.13 & 0 & 0 & 0.02 & 987 & 0.17 & 0.05 \\
\hline
\end{tabular}

Source: authors' elaboration on EU-LFS data. (1) Preferred scheme has replacement rate of 50\%, covers terminations of open-ended and fixed-term contracts, has maximum duration of 8 months and is activated by employment-based trigger. (2) Sum of squared deviations of unique contribution rate that balances the system for the EA as a whole from national contribution rate that balances the system for each country. (3) Percentage reduction in coefficient of variation of GDP over the time period. 
Table 2: Simulations of European UB schemes

\begin{tabular}{|c|c|c|c|c|c|c|c|c|c|c|c|}
\hline Study & Period & $\begin{array}{l}\text { Country } \\
\text { coverage }\end{array}$ & $\begin{array}{l}\text { No. of } \\
\text { simulations }\end{array}$ & $\begin{array}{l}\text { Benefit re- } \\
\text { placement rate }\end{array}$ & $\begin{array}{l}\text { Benefit } \\
\text { duration }\end{array}$ & $\begin{array}{l}\text { Labour force } \\
\text { coverage }\end{array}$ & Recipiency & $\begin{array}{l}\text { Activation } \\
\text { trigger }\end{array}$ & $\begin{array}{l}\text { Experience } \\
\text { rating }\end{array}$ & Tax base & $\begin{array}{l}\text { Macroeconomic } \\
\text { stabilisation }\end{array}$ \\
\hline \multicolumn{12}{|c|}{ Macroeconomic simulations } \\
\hline $\begin{array}{l}\text { Beblavý-Maselli } \\
\text { (2014) }\end{array}$ & 1999-2012 & EU28 & 4 & $\begin{array}{l}40 \% \text { mean } \\
\text { compensation }\end{array}$ & 6 months & $\begin{array}{l}\text { Short-term } \\
\text { unemployed }\end{array}$ & $75 \%$ & $\begin{array}{l}\text { Yes(unemploy- } \\
\text { ment)/No }\end{array}$ & Yes/No & $\begin{array}{l}\text { Employees’ } \\
\text { compensation/ } \\
\text { GDP }\end{array}$ & $\begin{array}{l}\text { Based on single } \\
\text { multiplier: } 1.5\end{array}$ \\
\hline $\begin{array}{l}\text { Beblavý et al. } \\
\text { (2015) }\end{array}$ & $2000-2012$ & EU27 & 3 & $\begin{array}{l}40 \% \text { mean } \\
\text { compensation }\end{array}$ & 12 months & $\begin{array}{l}\text { Short-term } \\
\text { unemployed }\end{array}$ & $80 \%$ & $\begin{array}{l}\text { Yes(short-term } \\
\text { unemployment, } \\
3 \text { thresholds) }\end{array}$ & Yes & GDP & $\begin{array}{l}\text { Based on single } \\
\text { multiplier: } 1.5\end{array}$ \\
\hline Dullien (2014a) & 1999-2012 & EA18 & 2 & $\begin{array}{l}40 \% \text { mean } \\
\text { earnings }\end{array}$ & 12 months & $\begin{array}{l}\text { Short-term } \\
\text { unemployed }\end{array}$ & $\begin{array}{l}50 \% / \text { Annual } \\
\text { change+20\% }\end{array}$ & No & No & $\begin{array}{l}\text { Wages and } \\
\text { salaries }\end{array}$ & $\begin{array}{l}\text { Based on single } \\
\text { multiplier: } 1\end{array}$ \\
\hline $\begin{array}{l}\text { Fichtner-Haan } \\
\text { (2014), Dullien } \\
\text { et al. (2014) }\end{array}$ & 1999-2012 & EA12 & 2 & $\begin{array}{l}\text { 30/70\% mean } \\
\text { net earnings }\end{array}$ & 6/12 months & $\begin{array}{l}\text { Short-term } \\
\text { unemployed }\end{array}$ & $\begin{array}{l}\text { Actual country } \\
\text { rate in fixed } \\
\text { year }\end{array}$ & No & No & $\begin{array}{l}\text { Wages and } \\
\text { salaries }\end{array}$ & $\begin{array}{l}\text { NiGEM macro- } \\
\text { economic simu- } \\
\text { lation model }\end{array}$ \\
\hline Epaulard (2014) & $2000-2015$ & EA12 & 2 & $\begin{array}{l}50 \% \text { mean } \\
\text { earnings }\end{array}$ & 9 months & $\begin{array}{l}\text { 4-12 month } \\
\text { unemployed }\end{array}$ & $80 \%$ & $\begin{array}{l}\text { Yes(unemploy- } \\
\text { ment)/No }\end{array}$ & No & $\begin{array}{l}\text { Wages and } \\
\text { salaries }\end{array}$ & $\begin{array}{l}\text { Based on single } \\
\text { multiplier: } 1\end{array}$ \\
\hline $\begin{array}{l}\text { Lellouch-Sode } \\
\text { (2014) }\end{array}$ & $2002-2012$ & EA12 & 2 & $\begin{array}{l}50 \% \text { mean } \\
\text { earnings }\end{array}$ & 12 months & Unemployed & $\begin{array}{l}0.5 \times(\text { actual } \\
\text { country rate }+ \\
\text { actual EA rate }) \\
\end{array}$ & No & $\begin{array}{l}\text { Yes(periodic } \\
\text { adjustment)/ } \\
\text { No }\end{array}$ & $\begin{array}{l}\text { Wages and } \\
\text { salaries }\end{array}$ & - \\
\hline \multicolumn{12}{|c|}{ Micro-simulations based on Euromod (EU-SILC 2008 wave, reweighted for other years) } \\
\hline $\begin{array}{l}\text { Dolls et al. } \\
\text { (2014) }\end{array}$ & $2000-2013$ & EA18 & 17 & $\begin{array}{l}\text { 33/50\% gross } \\
\text { earnings, with/ } \\
\text { without } \\
\text { national cap }\end{array}$ & $\begin{array}{l}12 \text { months } \\
\text { (with/without } 2 \\
\text { month waiting } \\
\text { period) }\end{array}$ & $\begin{array}{l}\text { Newly unem- } \\
\text { ployed with } \\
\text { positive labour } \\
\text { earnings }\end{array}$ & $\begin{array}{l}\text { 100\%/Actual } \\
\text { individual } \\
\text { evidence }\end{array}$ & $\begin{array}{l}\text { Yes(unemploy } \\
\text { ment)/No }\end{array}$ & Yes/No & $\begin{array}{l}\text { Employment } \\
\text { income (incl. } \\
\text { self-employed) }\end{array}$ & - \\
\hline $\begin{array}{l}\text { Jara-Sutherland } \\
\text { (2014) }\end{array}$ & 2012 & EA10 & 2 & $\begin{array}{l}50 \% \text { gross } \\
\text { earnings/33\% } \\
\text { mean gross } \\
\text { earnings }\end{array}$ & 9 months & $\begin{array}{l}\text { 4-12 month } \\
\text { unemployed, } \\
\text { with } 3 \text { month } \\
\text { contributions in } \\
\text { last } 12 \text { months }\end{array}$ & $100 \%$ & - & - & - & - \\
\hline \multicolumn{12}{|c|}{ Micro-simulations based on EU-LFS } \\
\hline This study & $2002-2012$ & EA10 & 1,728 & $35 / 50 \%$ wage & 3/8 months & $\begin{array}{l}\text { Job losers with } \\
\text { open-ended } \\
\text { and/or fixed- } \\
\text { term contracts }\end{array}$ & $\begin{array}{l}\text { 100\%/Actual } \\
\text { individual } \\
\text { evidence }\end{array}$ & $\begin{array}{l}\text { Yes(employ- } \\
\text { ment, output } \\
\text { gap)/No }\end{array}$ & Yes/Partial/No & Consumption & $\begin{array}{l}\text { Based on } 3 \text { pairs } \\
\text { of multipliers: } \\
(0.4,0.9),(1,1) \text {, } \\
(0.4,1.5)\end{array}$ \\
\hline
\end{tabular}

Source: authors’ elaboration. 
Figure A1: Shares on working age population of ILO unemployed and UB beneficiaries

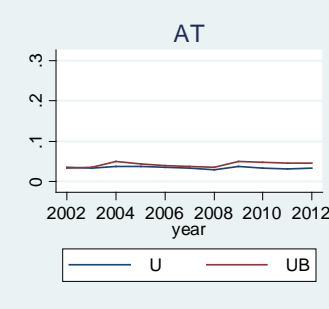

FR

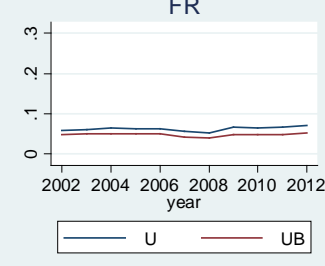

PT

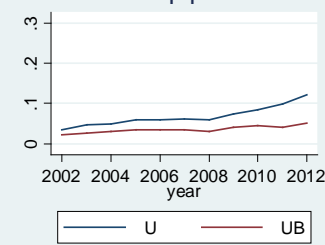

$\mathrm{BE}$

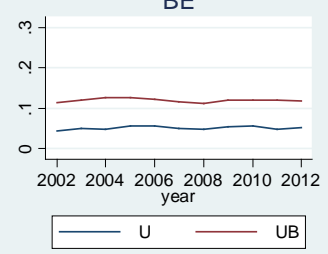

GR

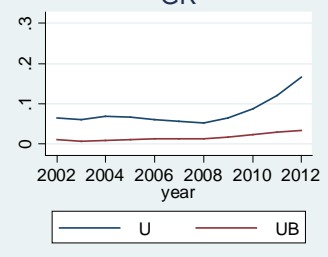

$\mathrm{SP}$

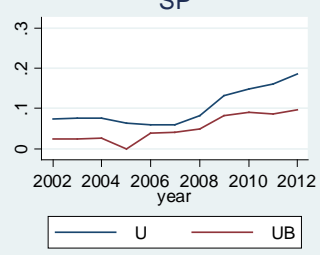

DE

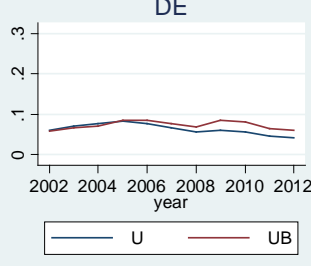

IT

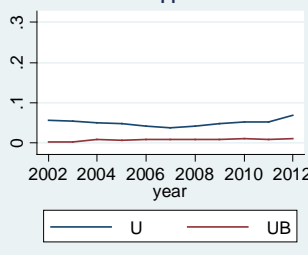

$\mathrm{FI}$

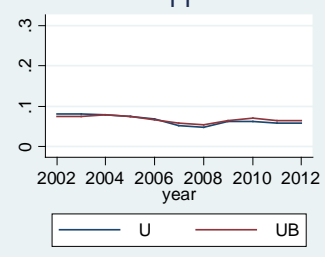

LU

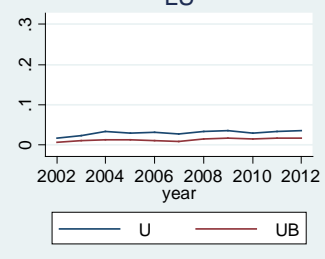

U ILO Unemployed; UB Unemployment beneficiaries

Source: authors' elaboration on EU-LFS data.

Figure A2: Previously open-ended contracts: take-up rates by duration
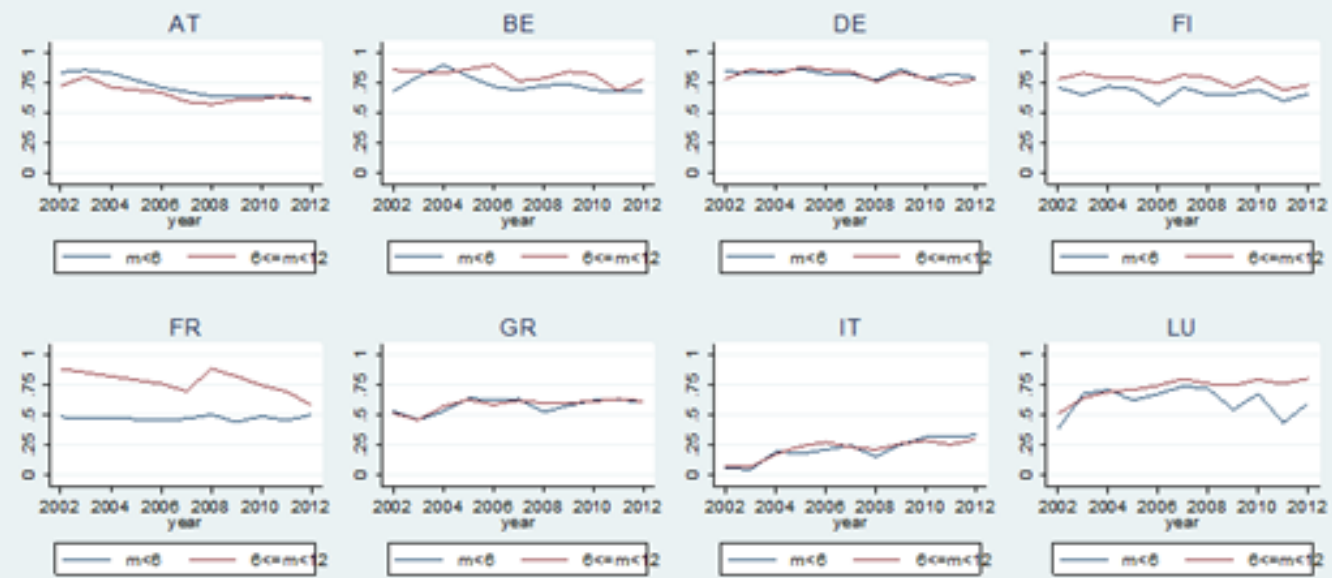

LU

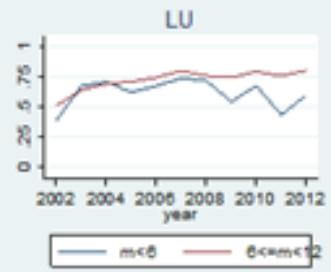

PT

SP
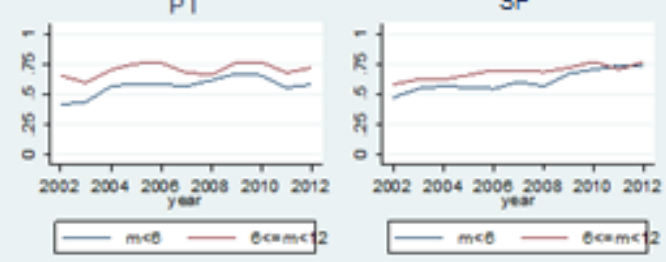

$m<6: 5$ months or less; $6<=m<12: 6$ to 11 months

Source: authors' elaboration on EU-LFS data. The graph shows the incidence of individuals receiving UB over the group of individuals who were employed with an open-ended contract a year before. 
Figure A3: Annual flows by country (\% of GDP)
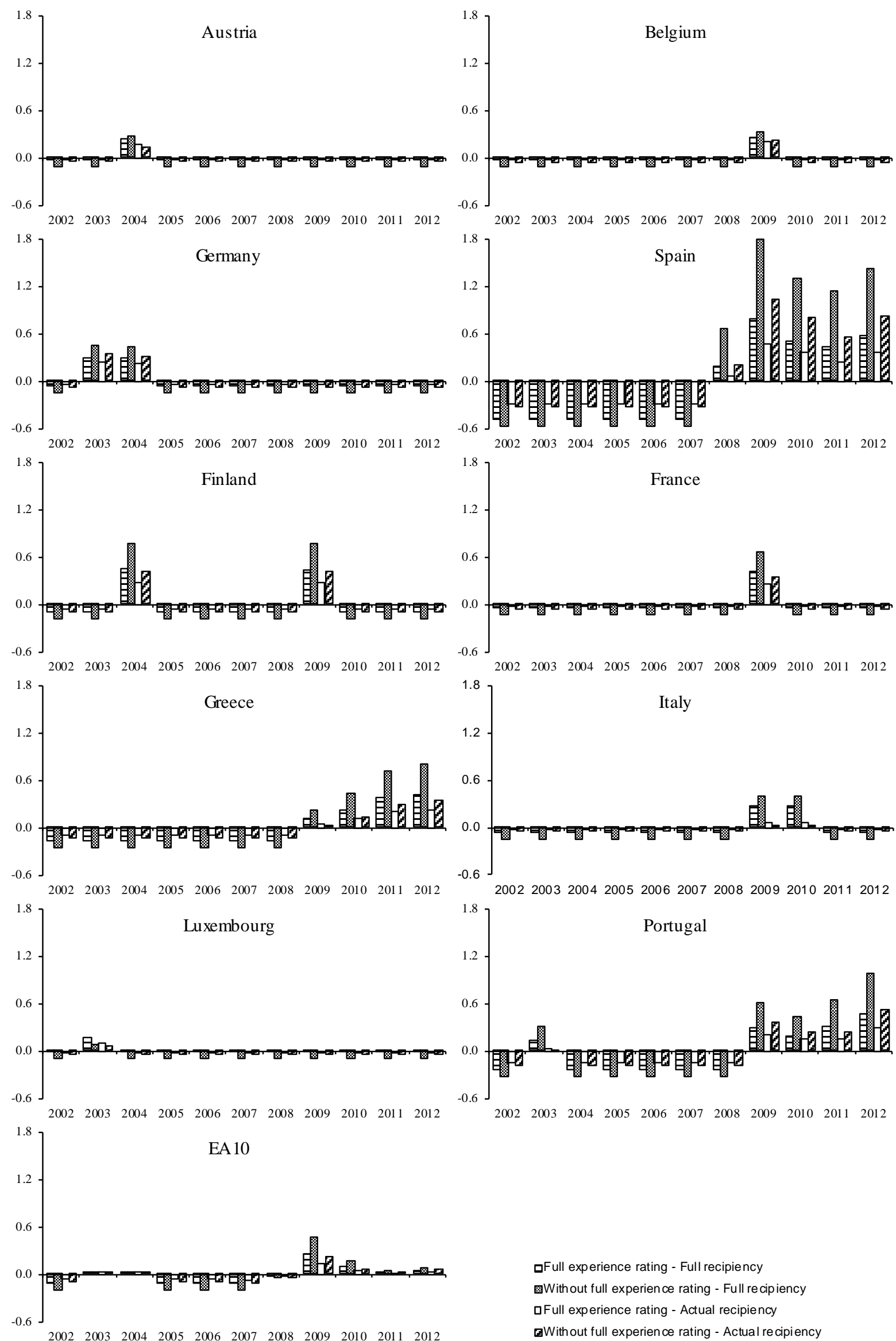

口Full experience rating - Full recipiency With out full experience rating - Full recipiency 口Full experience rating - Actual recipiency aWith out full experience rating - Actual recipiency

Source: authors' elaboration on EU-LFS data. 
Table A1: Robustness analysis

\begin{tabular}{|c|c|c|c|c|}
\hline Recipiency & Multipliers & Time interval & Best out of 24 schemes with full ER & Best out of 48 schemes with no or partial ER \\
\hline \multirow[t]{12}{*}{ Full } & Inflows: 0.9 & $2002-2012$ & RR 50\%; OEC+FTC; 8m; E trigger & RR 50\%; OEC+FTC; 8m; E trigger; partial ER \\
\hline & \multirow[t]{3}{*}{ Outflows 0.4} & $2002-2010$ & RR 50\%; OEC+FTC; 8m; OG trigger & RR 50\%; OEC+FTC; 8m; partial ER \\
\hline & & 2003-2011 & RR 50\%; OEC+FTC; 8m; E trigger & RR 50\%; OEC+FTC; 8m; partial ER \\
\hline & & 2004-2012 & RR 50\%; OEC+FTC; 8m; E trigger & RR 50\%; OEC+FTC; 8m; E trigger; partial ER \\
\hline & Inflows: 1 & 2002-2012 & RR 50\%; OEC ;8m; E trigger & RR 50\%; OEC+FTC; 8m; E trigger; no ER \\
\hline & \multirow[t]{3}{*}{ Outflows: 1} & 2002-2010 & RR 50\%; OEC ;8m; OG trigger & RR 50\%; OEC+FTC; 8m; partial ER \\
\hline & & 2003-2011 & RR 50\%; OEC ;8m; OG trigger & RR 50\%; OEC+FTC; 8m; partial ER \\
\hline & & 2004-2012 & RR 50\%; OEC ;8m; E trigger & RR 50\%; OEC+FTC; 8m; E trigger; partial ER \\
\hline & Inflows: 1.5 & $2002-2012$ & RR 50\%; OEC+FTC; 8m; E trigger & RR 50\%; OEC+FTC; 8m; E trigger; no ER \\
\hline & \multirow[t]{3}{*}{ Outflows: 0.4} & $2002-2010$ & RR 50\%; OEC+FTC; 8m; OG trigger & RR 50\%; OEC+FTC; 8m; partial ER \\
\hline & & 2003-2011 & RR 50\%; OEC+FTC; 8m; E trigger & RR 50\%; OEC+FTC; 8m; E trigger; partial ER \\
\hline & & 2004-2012 & RR 50\%; OEC+FTC; 8m; E trigger & RR 50\%; OEC+FTC; 8m; E trigger; partial ER \\
\hline \multicolumn{3}{|c|}{ Percentage of times best model is [RR 50\%; OEC+FTC; 8m; E trigger] } & $50 \%$ & $58 \%$ \\
\hline \multirow[t]{12}{*}{ Actual } & Inflows: 0.9 & $2002-2012$ & RR 50\%; OEC+FTC; 8m; E trigger & RR 50\%; OEC+FTC; 8m; E trigger; partial ER \\
\hline & \multirow[t]{3}{*}{ Outflows 0.4} & 2002-2010 & RR 50\%; OEC+FTC; 8m; & RR 50\%; OEC+FTC; 8m; OG trigger; partial ER \\
\hline & & 2003-2011 & RR 50\%; OEC+FTC; 8m; & RR 50\%; OEC+FTC; 8m; E trigger; partial ER \\
\hline & & 2004-2012 & RR 50\%; OEC+FTC; 8m; E trigger & RR 50\%; OEC+FTC; 8m; E trigger; partial ER \\
\hline & Inflows: 1 & 2002-2012 & RR 50\%; OEC+FTC; 8m; E trigger & RR 50\%; OEC+FTC; 8m; E trigger; no ER \\
\hline & \multirow[t]{3}{*}{ Outflows: 1} & 2002-2010 & RR 50\%; OEC; 8m; OG trigger & RR 50\%; OEC+FTC; 8m; OG trigger; partial ER \\
\hline & & 2003-2011 & RR 50\%; OEC; 8m; OG trigger & RR 50\%; OEC+FTC; 8m; E trigger; partial ER \\
\hline & & 2004-2012 & RR 50\%; OEC+FTC; 8m; E trigger & RR 50\%; OEC+FTC; 8m; E trigger; no ER \\
\hline & Inflows: 1.5 Outflows: & $2002-2012$ & RR 50\%; OEC+FTC; 8m; E trigger & RR 50\%; OEC+FTC; 8m; E trigger; partial ER \\
\hline & \multirow{3}{*}{0.4} & $2002-2010$ & RR 50\%; OEC+FTC; 8m; & RR 50\%; OEC+FTC; 8m; OG trigger; partial ER \\
\hline & & 2003-2011 & RR 50\%; OEC+FTC; 8m; & RR 50\%; OEC+FTC; 8m; E trigger; partial ER \\
\hline & & 2004-2012 & RR 50\%; OEC+FTC; 8m; E trigger & RR 50\%; OEC+FTC; 8m; E trigger; partial ER \\
\hline \multicolumn{3}{|c|}{ Percentage of times best model is [RR $50 \%$; OEC $+F T C ; 8 m ; E$ trigger] } & $50 \%$ & $75 \%$ \\
\hline
\end{tabular}

Source: authors' elaboration on EU-LFS data. Each row identifies a set of combinations of multipliers and time interval; the last two columns indicate the characteristics of best performing model in terms of stabilisation/redistribution: benefit replacement rate (RR), labour force coverage (OEC: termination of open-ended contract; FTC: termination of fixed-term contract); months of maximum duration (m); activation trigger variable (E: employment; OG: output gap); experience rating (ER). The scheme implying the lowest redistribution for given levels of stabilisation is in bold. 